\title{
ANALISIS PEMBATALAN AKTA HIBAH SAHAM DIDASARKAN PADA PERJANJIAN INVESTOR YANG TELAH DIBATALKAN (STUDI PUTUSAN KASASI NOMOR 2820 K/PDT/2014)
}

\author{
Su Hyon Son \\ (Mahasiswa Program S1 Fakultas Hukum Universitas Tarumanagara) \\ (E-mail : Sonsuhyon@gmail.com)
}

\author{
Stanislaus Atalim \\ (Corresponding Author)
}

(Dosen Hukum Perdata Fakultas Hukum Universitas Tarumanagara, Meraih Sarjana Hukum dari

Fakultas Hukum Universitas Indonesia, Magister Hukum dari Fakultas Hukum Universitas

Indonesia, Doktor Hukum dari Fakultas Hukum Universitas Parahyangan)

(E-mail : st_atalim@yahoo.com)

\begin{abstract}
According to article 1313 of Civil Code, the definition of an agreement is an act pursuant to which one or more individuals commit themselves to one another. Theoretically, an agreement that was made based on a previous made agreement makes this two agreements relate to one another and put them into a condition where the previous made agreement can terminate other agreement that has an attachment to it. This study is a normative legal research, where the results of this study are : first, the Judges' decision to terminate a grant deed was null and void by one of its considerations that was based on an investor agreement that by fact was made after the grant deed and had been canceled before the lawsuit was brought to court that made the decision uncertain. Second, the investor's agreement should not be taken as one of the judges' consideration to terminate the deed of grant, seeing that the two agreements are not related and can't be categorized as principal agreement and accesoir agreement. They both also have different standing in which the deed of grant is an notarial deed whereas the investor agreement is a private deed. So, the investor agreement can only be used as an evidence in court and cant be used as one of the judges' considerations to terminate the deed of grant.
\end{abstract}

Keywords : Investor Agreement, Terminate, Grant Deed 


\section{PENDAHULUAN}

\section{A. Latar Belakang}

Negara Indonesia adalah sebuah negara hukum seperti yang tercantum dalam Pasal 1 ayat (3) Undang-Undang Dasar 1945. Sebagai suatu negara hukum, perkembangan hukum untuk membawa Negara Indonesia menjadi suatu negara hukum yang lebih baik senantiasi terjadi, termasuk perkembangan di bidang hukum perdata. Perkembangan hukum perdata di Indonesia dipengaruhi oleh perkembangan hukum perdata pada negaranegara yang mempunyai hubungan langsung dengan Indonesia seperti negara Belanda dan Perancis. Indonesia yang pernah menjadi suatu negara dibawah pemerintahan Hindia Belanda membawa pada suatu keadaan dimana hukum yang berlaku di Indonesia tidak terlepas dari penerapan hukum di Belanda. Tidak hanya dipengaruhi oleh penerapan hukum di negara Belanda, perkembangan hukum perdata di Indonesia juga dipengaruhi oleh negara yang pernah menjajah Belanda yaitu negara Perancis.

Mengenai pengertian dari Hukum Perdata itu sendiri, menurut Subekti Hukum Perdata memiliki pengertian dalam arti luas meliputi semua hukum yang disebut sebagai "privat materiel", yaitu segala hukum pokok yang mengatur hak-hak dan kewajiban perdata, serta mengatur kepentingan-kepentingan perdata setiap subjek hukum ${ }^{1}$ ). Sedangkan menurut Sudikno Mertokusumo, Hukum Perdata adalah hukum antarperorangan yang mengatur hak dan kewajiban perorangan yang satu terhadap yang lain didalam hubungan keluarga dan di dalam pergaulan masyarakat. ${ }^{2)}$ Dari pendapat kedua ahli tersebut dapat dikatakan bahwa pengertian dari Hukum Perdata adalah serangkaian ketentuan mengenai ketertiban baik tertulis maupun tidak tertulis yang mengatur hak dan kewajiban perorangan yang satu terhadap yang lain dalam hubungan keluarga dan didalam pergaulan masyarakat. Hukum Perdata berdasarkan

${ }^{1)}$ Subekti, Pokok-Pokok Hukum Perdata, (Jakarta: intermasa, 2010), hal. 9.

2 ) Sudikno Mertokusumo, Mengenal Hukum Suatu Pengantar, (Yogyakarta: Liberty, 1986), hal. 108. 
Ilmu Pengetahuan dapat dibagi menjadi 4 macam, dimana dalam Buku I tentang Orang mengatur hak, kewajiban, dan kedudukan seseorang didalam Hukum Perdata dari sejak orang tersebut hidup sampai kepada saat orang tersebut meninggal. Manusia sebagai makhluk sosial banyak melakukan interaksi antar satu sama lain yang salah satunya adalah melakukan hubungan hukum yang kemudian melahiran hak dan kewajiban yang berlaku secara timbal balik terhadap manusia-manusia tersebut. Salah satu hubungan hukum yang kemudian melahirkan hak dan kewajiban tersebut adalah dengan melakukan perjanjian. Perjanjian Menurut Subekti adalah suatu peristiwa dimana seseorang berjanji kepada orang lain atau dimana dua orang itu saling berjanji melaksanakan suatu dalam bentuk perjanjian berupa suatu rangkaian perkataan yang diucapkan atau ditulis. Kitab Undang-Undang Hukum Perdata mengenal berbagai jenis perjanjian $^{3)}$ yang salah satunya adalah perjanjian cuma-cuma.

Perjanjian cuma-cuma dikenal sebagai suatu perjanjian dimana pihak yang satu memberikan suatu keuntungan kepada pihak yang lain tanpa menerima suatu manfaat bagi dirinya. Salah satu contoh dari perjanjian cuma-cuma adalah perjanjian hibah, pinjam pakai, pinjam meminjam tanpa bunga, dan penitipan barang tanpa biaya. ${ }^{4}$ Perjanjian Hibah merupakan sebuah perjanjian yang digolongkan dalam perjanjian cumacuma, dalam perkataan dengan cuma-cuma ditunjukkan adanya prestasi dari satu pihak saja, sedang pihak lainnya tidak usah memberikan kontra prestasinya."5) Disebutkan dalam Pasal 1666 KUHPerdata bahwa Hibah adalah suatu perjanjian dengan mana si penghibah, di waktu hidupnya, dengan cuma-cuma dan dengan tidak dapat ditarik kembali, menyerahkan sesuatu benda guna keperluan si penerima hibah yang menerima

3) Ada 14 jenis perjanjian antara lain :a. Perjanjian timbal balik; b. Perjanjian CumaCuma; c. Perjanjian atas beban; d. Perjanjian bernama; f. Perjanjian Obligatoir; g. Perjanjian Kebendaan; h. Perjanjian konseptual; i. Perjanjian riil; j. Perjanjian Liberatori; k.Perjanjian Pembuktian; m. Perjanjian Untung-Untungan; n. Perjanjian Publik; o. Perjanjian Campuran, R. subekti, Hukum Perjanjian, (Jakarta : Intermasa, 1979), hal. 66.

${ }^{4)}$ Wibowo Tunardy, http://www.jurnalhukum.com/jenis-jenis-perjanjian/, 10 Mei 2018

${ }^{5)}$ Subekti, Aneka Perjanjian, (Bandung : Citra Aditya Bakti,1995), hal. 94. 
penyerahan itu. Pasal 1667 KUHPerdata mengatakan bahwa suatu hibah hanya dapat dilakukan atas benda-benda (barang atau harta) yang sudah ada (tegenwoordige goederen) yaitu harta yang sudah menjadi milik pemberi hibah pada saat perjanjian hibah dibuat, dan jika hibah atas barang yang baru kemudian akan ada, maka hibah atas harta-harta itu batal. ${ }^{6)}$

Penghibahan atas saham dalam suatu perusahaan yang dilakukan antara penghibah dengan penerima hibah adalah salah satu contoh penghibahan atas benda-benda yang sudah ada. Saham sebagai objek dari suatu penghibahan dikategorikan sebagai benda bergerak seperti yang tercantum dalam Pasal 60 Undang-Undang no 40 tahun 2007 tentang Perseroan Terbatas ("UU PT"). Saham itu sendiri memiliki pengertian sebagai suatu bukti penyetoran modal seseorang dalam sebuah perusahaan. Sebagaimana diatur dalam Undang-Undang No 8 tahun 1997 tentang Dokumen Perusahaan;
"Perusahaan adalah setiap bentuk usaha yang melakukan kegiatan secara tetap dan terus menerus dengan tujuan memperoleh laba atau keuntungan, baik yang diselenggarakan oleh orang perseorangan maupun oleh badan usaha (perkumpulan/organisasi) baik yang berbentuk badan hukum maupun bukan yang didirikan dan berkedudukan di dalam wilayah negara RI" ${ }^{\text {, }}$

Saham sebagai bukti penyetoran modal seseorang dalam sebuah perusahaan tercermin dari definisi Perseroan Terbatas dalam Pasal 1 angka 1 UU PT yang berbunyi:

"Perseroan Terbatas, yang selanjutnya disebut Perseroan, adalah badan hukum yang merupakan persekutuan modal, didirikan berdasarkan perjanjian, melakukan kegiatan usaha dengan modal dasar yang seluruhnya terbagi dalam saham dan memenuhi persyaratan yang ditetapkan dalam Undang-undang ini serta peraturan pelaksanaanya." ${ }^{8)}$

Saham sebagai benda bergerak memberikan hak sebagaimana

\footnotetext{
${ }^{6)}$ Indonesia, KUHPerdata

${ }^{7)}$ Indonesia, Undang-Undang Nomor 8 tahun 1997 tentang Dokumen Perusahaan pasal 8.

${ }^{8)}$ Indonesia, Undang-Undang Nomor 40 tahun 2007 tentang Perseroan Terbatas pasal 1
} angka 1. 
dimaksud dalam Pasal 52 kepada pemiliknya. ${ }^{9)}$ Sentosa Sembiring mengatakan bahwa saham adalah benda bergerak yang memberikan hak kebendaan bagi pemiliknya. ${ }^{10}$ ) Hak-hak pemegang saham lahir dari kebendaan tersebut. Saham yang dimiliki oleh pemegang saham memberikan hak kepada pemegang saham, antara lain sebagai berikut :

1. Hak memesan terlebih dahulu

Seluruh saham yang dikeluarkan untuk penambahan modal harus terlebih dahulu ditawarkan kepada setiap pemegang saham seimbang dengan pemilikan saham untuk klasifikasi saham yang sama. (Pasal 43 UU PT);

2. Hak mengajukan gugatan ke Pengadilan

Setiap pemegang saham berhak mengajukan gugatan terhadap Perseroan ke Pengadilan Negeri Apabila dirugikan karena tindakan Perseroan yang dianggap tidak adil dan tanpa alasan wajar sebagai akibat keputusan Rapat Umum Pemegang Saham ("RUPS”), Direksi, dan/atau Dewan Komisaris. (Pasal 61 UU PT);

3. Hak saham dibeli dengan harga wajar

Setiap pemegang saham berhak meminta kepada Perseroan agar sahamnya dibeli dengan harga yang wajar apabila yang bersangkutan tidak menyetujui tindakan Perseroan yang merugikan pemegang saham atau Perseroan berupa:

a. Perubahan Anggaran Dasar ("AD");

b. Pengalihan atau penjaminan kekayaan perseroan yang mempunyai nilai lebih dari 50\% (lima puluh persen) kekayaan bersih Perseroan; atau

c. Penggabungan, Peleburan, Pengambilalihan, atau Pemisahan. (Pasal 62 UU PT).

4. Hak meminta ke pengadilan negeri untuk menyelenggarakan RUPS

9) Indonesia, Undang-Undang Nomor 40 tahun 2007 tentang Perusahaan Pasal 60 Ayat (1).

10) Sentosa Sembiring, Hukum Perusahaan Tentang Perseroan Terbatas, Nuansa, (Bandung : Nuansa Aulia, 2006), hal. 43. 
Dalam hal Direksi atau Dewan Komisaris tidak melakukan pemanggilan RUPS dalam jangka waktu yang telah ditentukan, maka Pemegang saham yang meminta penyelenggaraan RUPS dapat mengajukan permohonan kepada Ketua Pengadilan Negeri yang daerah hukumnya meliputi tempat kedudukan Perseroan untuk menetapkan pemberian izin kepada pemohon untuk melakukan sendiri pemanggilan RUPS tersebut (Pasal 80 UUPT);

5. Hak menghadiri RUPS

Pemegang saham, baik sendiri maupun diwakili berdasarkan surat kuasa berhak menghadiri RUPS dan menggunakan hak suaranya sesuai dengan jumlah saham yang dimilikinya. (Pasal 85 Ayat (1) UU PT).

Dalam UU PT, pengaturan mengenai pengalihan hak milik atas saham dijelaskan dalam Pasal 55 sampai dengan Pasal 59. Pengalihan hak milik atas saham wajib memenuhi syarat :

1. Pasal 55 UUPT :

Dalam anggaran Dasar Perseroan ditentukan cara pemindahan hak atas saham sesuai dengan peraturan perundang-undangan.

2. Pasal 56 ayat (1) UUPT :

Pemindahan hak atas saham atas nama dilakukan dengan akta pemindahan hak.

Saham sebagai benda bergerak seperti yang tercantum dalam Pasal 60 ayat (1) UUPT dapat dijual-belikan dan juga dialihkan. Pemindahan hak milik atas saham dengan cara hibah wajib menggunakan Akta Notaris dengan mengacu kepada Pasal 55 UUPT dan Pasal 1682 KUHPerdata yang berbunyi "Tiada suatu penghibahan pun, kecuali penghibahan termaksud dalam pasal 1687, dapat dilakukan tanpa akta notaris." Berhubungan dengan pengalihan hak milik atas saham melalui hibah, baru-baru ini di Indonesia telah terjadi kasus pengalihan hak milik atas saham melalui hibah antara 2 pemegang saham dari PT Ridlatama Trade Powerindo dengan PT Techno Coal Utama Prima dan PT Indonesian Coal Developments. Bermula dari PT Techno Coal Utama Prima, sebuah 
perusahaan yang bergerak di bidang pertambangan yang merupakan anak perusahaan dari Churchill Mining Plc (sebuah perusahaan pertambangan yang terdaftar di Inggris), berminat untuk membeli 75\% (tujuh puluh lima persen) saham yang dimiliki oleh Anita Setiawan dan Florita yang merupakan pemegang saham dari PT Ridlatama Trade Powerindo dengan masing-masing kepemilikan saham sebanyak 5000 (lima ribu) lembar atau sebesar 50\% (lima puluh) persen. PT Techno Coal Utama Prima menjanjikan untuk membayar kepada Anita Setiawan dan Florita untuk 75\% (tujuh puluh lima) persen saham tersebut. Kemudian para pihak melakukan pengalihan hak milik atas saham sebesar 75\% (tujuh puluh lima persen) melalui hibah kepada PT Indonesian Coal Developments yang ditunjuk oleh PT Tecno Coal Utama Prima untuk menguasai dan memiliki saham-saham tersebut. Pada tanggal 26 November 2007, Ani Setiawan dan Florita melakukan hibah saham berdasarkan Akta Hibah Saham Nomor 12 tanggal 26 November 2007 dan Akta Hibah Saham Nomor 13 tanggal 26 November 2007 sehingga 75\% (tujuh puluh lima persen) saham atau sebanyak 7.500 (tujuh ribu lima ratus) lembar saham milik Anita Setiawan dan Florita di PT Ridlatama Trade Powerindo beralih kepada PT Indonesian Coal Developments. Kemudian pada tanggal 28 November 2007 ditandatangani Investor Agreement 2007 ("Perjanjian Investasi 2007") antara Ani Setiawan, Florita, PT Ridlatama Trade Powerindo, PT Techno Coal Prima Utama, dan PT Indonesian Coal Developments untuk mengesahkan kembali janji-janji PT Techno Coal Utama Prima dan PT Indonesian Coal Developments kepada Ani Setiawan dan Florita sehubungan dengan minat investasi PT Techno Coal Utama Prima dan PT Indonesian Coal Developments pada Konsesi Pertambangan Ani Setiawan dan Florita. Bahwa PT Techno Coal Utama Prima dan PT Indonesian Coal Developments menyatakan dalam Perjanjian Investasi 2007, secara khusus untuk 75\% (tujuh puluh lima persen) saham milik Anita Setiawan dan Florita di PT Ridlatama Trade Powerindo telah dibayarkan secara penuh. Pada tanggal 27 Januari 2011, PT Indonesian 
Coal Developments yang telah menguasai seluruh saham PT Ridlatama Trade Powerindo meminta Ani Setiawan dan Florita untuk menandatangani Deed of Termination and Release ("Perjanjian Pengakhiran dan Pelepasan") yang pada intinya mengakhiri Perjanjian Investor 2007, dimana kemudian Ani Setiawan dan Florita menyetujuinya. Pada tingkat Pengadilan Negeri, kasus ini dimenangkan oleh Ani setiawan dan Florita dengan dibatalkannya akta hibah oleh Hakim atas dasar adanya Perjanjian Investor yang telah diakhiri oleh para pihak. Kemudian pihak PT Techno Coal Utama Prima mengajukan banding dan juga kasasi yang oleh Hakim diputuskan tetap dimenangkan oleh pihak Ani Setiawan dan Florita dengan dibatalkannya Akta Hibah yang telah dibuat. Pertimbangan Hakim untuk membatalkan Akta Hibah didasarkan pada pasal 1365 KUHPerdata, bahwa PT Techno Coal Utama Prima dan PT Indonesian Coal Developments telah melakukan Perbuatan Melawan Hukum dan bahwa Akta Hibah tersebut tidak memenuhi salah satu syarat sebuah Akta Hibah karena adanya suatu syarat pembayaran dalam Perjanjian investor yang telah melanggar hukum.

Menjadi suatu permasalahan ketika Perjanjian Investor yang telah diakhiri oleh para pihak dengan Akta Pengakhiran dan Pelepasan, kemudian dijadikan sebagai salah satu pertimbangan Hakim untuk membatalkan Akta Hibah pengalihan hak milik atas saham, yang mana Akta Hibah pengalihan hak milik atas saham tesebut tidak dibuat berdasarkan perjanjian investor karena Perjanjian Investor tersebut lahir setelah adanya Akta Hibah. Maka sebagai suatu upaya untuk dapat menjawab persoalan yang ada, diangkatlah judul penelitian "ANALISIS PEMBATALAN AKTA HIBAH SAHAM DIDASARKAN PADA PERJANJIAN INVESTOR YANG TELAH DIBATALKAN (Studi Putusan Mahkamah Agung Nomor 2820 K/Pdt/2014)"

\section{B. Perumusan Masalah}


Berdasarkan uraian latar belakang tersebut maka adapun rumusan masalah dalam penelitian ini adalah:

1. Bagaimana Perjanjian Investor yang telah dibatalkan oleh para pihak dapat dijadikan sebagai salah satu pertimbangan Hakim dalam memutus Putusan Mahkamah Agung Nomor 2820 K/Pdt/2014?

2. Bagaimana Kedudukan Perjanjian Investor terhadap Akta Hibah berdasarkan Putusan Mahkamah Agung Nomor 2820 K/Pdt/2014?

\section{Pembahasan}

Latar belakang dari permasalahan kasus yang diangkat dimulai dari terjadinya suatu peristiwa hukum yaitu pengalihan hak milik atas saham melalui hibah. Telah terjadi kasus pengalihan hak milik atas saham melalui hibah di Indonesia antara 2 pemegang saham dari PT Ridlatama Trade Powerindo dengan PT Techno Coal Utama Prima dan PT Indonesian Coal Developments. Bermula dari PT Techno Coal Utama Prima, sebuah perusahaan yang bergerak di bidang pertambangan yang merupakan anak perusahaan dari Churchill Mining Plc (sebuah perusahaan pertambangan yang terdaftar di Inggris), berminat untuk membeli 75\% (tujuh puluh lima persen) saham yang dimiliki oleh Anita Setiawan dan Florita yang merupakan pemegang saham dari PT Ridlatama Trade Powerindo dengan masing-masing kepemilikan saham sebanyak 5000 (lima ribu) lembar atau sebesar 50\% (lima puluh) persen. PT Techno Coal Utama Prima menjanjikan untuk membayar kepada Anita Setiawan dan Florita untuk 75\% (tujuh puluh lima) persen saham tersebut. Kemudian para pihak melakukan pengalihan hak milik atas saham sebesar 75\% (tujuh puluh lima persen) melalui hibah kepada PT Indonesian Coal Developments yang ditunjuk oleh PT Tecno Coal Utama Prima untuk menguasai dan memiliki saham-saham tersebut.

Pada tanggal 26 November 2007, Ani Setiawan dan Florita melakukan hibah saham berdasarkan Akta Hibah Saham Nomor 12 
tanggal 26 November 2007 dan Akta Hibah Saham Nomor 13 tanggal 26 November 2007 sehingga 75\% (tujuh puluh lima persen) saham atau sebanyak 7.500 (tujuh ribu lima ratus) lembar saham milik Anita Setiawan dan Florita di PT Ridlatama Trade Powerindo beralih kepada PT Indonesian Coal Developments. Kemudian pada tanggal 28 November 2007 ditandatangani Investor Agreement 2007 ("Perjanjian Investasi 2007”) antara Ani Setiawan, Florita, PT Ridlatama Trade Powerindo, PT Techno Coal Prima Utama, dan PT Indonesian Coal Developments untuk mengesahkan kembali janji-janji PT Techno Coal Utama Prima dan PT Indonesian Coal Developments kepada Ani Setiawan dan Florita sehubungan dengan minat investasi PT Techno Coal Utama Prima dan PT Indonesian Coal Developments pada Konsesi Pertambangan Ani Setiawan dan Florita. Bahwa PT Techno Coal Utama Prima dan PT Indonesian Coal Developments menyatakan dalam Perjanjian Investasi 2007, secara khusus untuk 75\% (tujuh puluh lima persen) saham milik Anita Setiawan dan Florita di PT Ridlatama Trade Powerindo telah dibayarkan secara penuh. Pada tanggal 27 Januari 2011, PT Indonesian Coal Developments yang telah menguasai seluruh saham PT Ridlatama Trade Powerindo meminta Ani Setiawan dan Florita untuk menandatangani Deed of Termination and Release ("Perjanjian Pengakhiran dan Pelepasan") yang pada intinya mengakhiri Perjanjian Investor 2007, dimana kemudian Ani Setiawan dan Florita menyetujuinya. Pada tingkat Pengadilan Negeri, kasus ini dimenangkan oleh Ani setiawan dan Florita dengan dibatalkannya akta hibah oleh Hakim atas dasar adanya Perjanjian Investor yang telah diakhiri oleh para pihak. Kemudian pihak PT Techno Coal Utama Prima mengajukan banding dan juga kasasi yang oleh Hakim diputuskan tetap dimenangkan oleh pihak Ani Setiawan dan Florita dengan dibatalkannya Akta Hibah yang telah dibuat. Pertimbangan Hakim untuk membatalkan Akta Hibah didasarkan pada pasal 1365 KUHPerdata, bahwa PT Techno Coal Utama Prima dan PT Indonesian Coal Developments telah melakukan Perbuatan 
Melawan Hukum dan bahwa Akta Hibah tersebut tidak memenuhi salah satu syarat sebuah Akta Hibah karena adanya suatu syarat pembayaran dalam Perjanjian investor yang telah melanggar hukum.

Menjadi suatu permasalahan ketika Perjanjian Investor yang telah diakhiri oleh para pihak dengan Akta Pengakhiran dan Pelepasan, kemudian dijadikan sebagai salah satu pertimbangan Hakim untuk membatalkan Akta Hibah pengalihan hak milik atas saham, yang mana Akta Hibah pengalihan hak milik atas saham tesebut tidak dibuat berdasarkan perjanjian investor karena Perjanjian Investor tersebut lahir setelah adanya Akta Hibah.

\section{A. Tentang Perjanjian Investor yang telah diakhiri oleh para pihak} yang kemudian dijadikan sebagai salah satu pertimbangan Hakim dalam memutus Putusan Mahkamah Agung Nomor 2820 K/Pdt/2014

Berdasarkan Pasal 1313 KUHPerdata, perjanjian adalah Perbuatan dengan mana satu orang atau lebih mengikatkan dirinya terhadap satu orang lain atau lebih. Dari peristiwa ini, timbulah suatu hubungan hukum antara dua orang atau lebih yang disebut Perikatan yang didalamya terdapat hak dan kewajiban masing-masing pihak. Sebelum membahas lebih lanjut tentang perjanjian investor yang telah dibatalkan oleh para pihak yang kemudian dijadikan sebagai salah satu pertimbangan Hakim dalam memutus Putusan Mahkamah Agung Nomor 2820 K/Pdt/2014, pertama-tama yang akan dibahas terlebih dahulu adalah tentang makna penting dari perjanjian itu sendiri. Perjanjian menurut Subekti adalah suatu peristiwa di mana seorang berjanji kepada orang lain atau di mana dua orang itu saling berjanji untuk melaksanakan sesuatu hal. ${ }^{11)}$ Ibu Ning Adiasih berpendapat bahwa setiap perjanjian haruslah memenuhi Pasal

\footnotetext{
${ }^{11)}$ Subekti, Hukum Perjanjian, Cetakan ke-18. (Jakarta: Intermasa, 2001), hal. 1.
} 
1320 KUHPerdata mengenai syarat sahnya suatu perjanjian ${ }^{12}$, yang meliputi :

1. Sepakat;

2. Cakap;

3. Suatu hal tertentu;

4. Suatu sebab yang halal

Secara teori, Perjanjian yang dibuat secara sah menurut pasal 1338 KUHPerdata akan mengikat sebagai Undang-Undang bagi mereka yang membuatnya dan mengikat kedua belah pihak. Pada kenyataan yang ada, salah satu pertimbangan Hakim yang meyakini bahwa perjanjian investor lahir dengan dilatarbelakangi oleh akta hibah saham dan adanya suatu syarat pembayaran yang tercantum dalam perjanjian investor, membuat hal tersebut sudah jelas bertentangan dengan teori hibah. Pasal 1666 KUHPerdata mengatakan bahwa hibah dilakukan dengan cuma-cuma sedangkan perjanjian investor tersebut mencantumkan adanya suatu syarat pembayaran sehingga tidak sesuai dengan teori Hibah yang ada. Jadi yang seharusnya terjadi adalah perjanjian investor tersebut batal demi hukum karena tidak sesuai dengan teori hibah dan akta hibah lah yang tetap hidup. Walaupun demikian, dengan berdasarkan pada pemaparan teori tentang perjanjian yang telah paparkan sebelumnya, hasil wawancara yang telah dilakukan dengan Bu Ning Adiasih, dan pada fakta yang ada yaitu dengan melihat secara langsung isi dari perjanjian investor bahwa perjanjian tersebut tidak ada kaitannya dengan akta hibah dan lahir tidak dilatarbelakangi oleh akta hibah, namun perjanjian yang dilakukan antar pihak pada kasus ini dibuat secara sah karena telah memenuhi syarat sahnya suatu perjanjian seperti yang tercantum dalam Pasal 1320 KUHPerdata. Perjanjian tersebut tidak lahir dengan dilatarbelakangi oleh akta hibah karena tidak adanya keterkaitan antara

12 ) Peneliti, Wawancara, dengan Ning Adiasih, (Jakarta: Universitas Tarumanagara Jakarta

Barat, 25 April 2018). 
kedua perjanjian, dan bahwa perjanjian investor tersebut berdasarkan pada Pasal 1338 KUHPerdata berlaku seperti Undang-Undang yang mengikat para pihak.

Dalam kasus ini, perjanjian yang telah disepakati oleh antar pihak adalah perjanjian investor. Didalam putusan Mahkamah Agung Nomor $2820 \mathrm{~K} / \mathrm{Pdt} / 2014$, dapat dilihat bahwa Perjanjian Investor yang telah dibatalkan oleh para pihak dengan Akta Pengakhiran dan Pelepasan dalam kasus ini dijadikan sebagai salah satu pertimbangan Hakim dalam memutus Putusan Mahkamah Agung Nomor 2820 K/Pdt/2014 yakni memutuskan bahwa Akta Hibah yang dibuat oleh para pihak batal demi hukum dan adanya unsur "kesalahan" dari Tergugat sesuai Pasal 1365 KUHPerdata sehingga dikategorikan sebagai suatu perbuatan melawan hukum yang dilakukan Tergugat. Salah satu hal yang dilihat oleh Hakim sehingga mengkategorikan Tergugat telah melakukan perbuatan melawan hukum adalah bahwa terdapat suatu syarat pembayaran dalam ketentuan perjanjian pasal 3.1 pada perjanjian investor tersebut. Apabila melihat pada ketentuan perjanjian pasal 3.1 dalam perjanjian investor yang tercantum dalam putusan yakni adanya syarat pembayaran yang telah disepakati bersama tetapi tidak dilaksanakan, maka benar bahwa Hakim melihat adanya perbuatan melawan hukum oleh Tergugat kepada Penggugat dengan tidak membayarkan sejumlah uang yang dijanjikan untuk dibayarkan sehingga memutus akta hibah batal demi hukum dan bahwa Tergugat telah melakukan Perbuatan Melawan Hukum. Tetapi kemudian melihat pada fakta yang ada, terdapat perbedaan makna dari beberapa kata terjemahan Bahasa Inggris ke Bahasa Indonesia antara ketentuan pasal 3.1 perjanjian investor yang tercantum dalam Putusan Mahkamah Agung Nomor 2820 K/Pdt/2014 dengan ketentuan pasal 3.1 perjanjian investor yang diserahkan oleh pihak Tergugat kepada pengadilan sebagai salah satu bukti dalam kasus ini. Kesalahan terjemahan pada beberapa kata ini bisa saja dimungkinkan atas dasar kesalahan ketik dari panitera, yang mengakibatkan makna atau dampak 
hukum yang berbeda. Makna terjemahan yang berbeda yang tercantum dalam suatu putusan memungkinkan Hakim jadi salah penafsiran dan berdampak pada putusan Hakim tersebut.

Putusan Hakim dalam suatu perkara berkaitan dengan teori Argumentasi yang pada dasarnya adalah penampilan proses kegiatan berpikir. ${ }^{13}$ Teori argumentasi mengkaji bagaimana menganalisis dan merumuskan suatu argumentasi secara tepat. Teori argumentasi mengembangkan kriteria yang dijadikan dasar untuk argumentasi yang jelas dan rasional. ${ }^{14)}$ Jadi dengan merujuk pada teori argumentasi hakim yang telah dipaparkan diatas, melihat bahwa salah satu pertimbangan Hakim menyatakan bahwa adanya syarat pembayaran dalam terjemahan ketentuan Perjanjian Investor Pasal 3.1 yang tercantum didalam putusan pada faktanya tidak sesuai dengan terjemahan Perjanjian Investor yang telah diserahkan oleh pihak Kuasa Hukum Tergugat ke Pengadilan, maka kesalahan terjemahan tersebut mengakibatkan makna atau dampak hukum yang berbeda. Makna terjemahan yang berbeda yang tercantum dalam suatu putusan memungkinkan suatu kondisi yang menyebabkan Hakim menjadi salah menafsirkan dan berdampak pada putusan yang diberikan. Suatu penerjemahan bahasa merupakan salah satu hal penting bagi Hakim untuk memutus suatu perkara yang apabila terjadi kesalahan penerjemahan bahasa baik disengaja maupun tidak disengaja, maka akan mempengaruhi putusan Hakim tersebut.

Perjanjian yang dilakukan antar pihak tersebut dapat berakhir. Berakhirnya suatu perjanjian atau perikatan diatur dalam Pasal 1381 KUHPerdata, yang menyebutkan sepuluh cara hapusnya suatu perikatan. Cara-cara tersebut adalah:

1)Pembayaran;

13) Arif Sidharta, Karakteristik Penalaran Hukum dalam Konteks Keindonesiaan, (Bandung: CV. Utomo,2006), hal. 163

14) Philipus Hendrik Rapar, Argumentasi Hukum, (Yogyakarta : Penerbit Gajah Mada University Press, 2009) Cetakan keempat, hal. 13. 
2)Penawaran pembayaran tunai diikuti dengan penyimpanan atau penitipan;

3)Pembaharuan utang;

4)Perjumpaan utang atau kompensasi;

5)Percampuran utang;

6)Pembebasan utang;

7)Musnahnya barang yang terutang;

8)Batal/pembatalan;

9)Berlakunya suatu syarat batal; dan

10) Lewatnya waktu.

Sepuluh cara di atas belum lengkap, karena masih ada cara-cara yang tidak disebutkan, misalnya berakhirnya suatu ketetapan waktu ("termijn") dalam suatu perjanjian atau meninggalnya salah satu pihak dalam beberapa macam perjanjian. ${ }^{15)}$ Melihat pada kasus ini, apabila Perjanjian Investor yang kemudian dibatalkan dengan Akta Pengakhiran dan Pelepasan dengan kesepakatan kedua belah pihak dapat membuktikan kebenaran dari Pasal 3.1 dalam Perjanjian Investor yang menyatakan bahwa telah dilakukan suatu pembayaran, maka hapusnya perjanjian investor adalah dengan telah dilakukannya pembayaran. Tetapi oleh karena tidak adanya hitam diatas putih atau bukti lain yang dapat menguatkan bahwa pembayaran sebagaimana dicantum dalam Pasal 3.1 dalam Perjanjian Investor memang benar telah dilakukan, maka dapat disiimpulkan bahwa perjanjian investor tersebut berakhir bukan karena adanya pembayaran atau bukan dengan cara pembayaran, tetapi dengan cara batal atau pembatalan sebagaimana nomor 8 dari cara-cara untuk hapusnya suatu perjanjian yang telah dicantumkan diatas. Mengapa hal ini menjadi penting untuk dibahas? Bahwa haruslah dijelaskan secara jelas tentang sebab dari pengakhiran dari Perjanjian Investor dalam kasus ini dengan melihat pada fakta yang ada. Perbedaan antara pengakhiran Perjanjian yang disebabkan karena pembayaran dan pembatalan adalah :

\footnotetext{
${ }^{15)}$ Subekti, Op.cit., hal. 64.
} 
1. Pembayaran : Suatu perjanjian dapat berakhir atau hapus karena sebab pembayaran. Contohnya dalam perjanjian utang-piutang. Pak D (Debitur) meminjam uang kepada Bank K (Kreditur) sejumlah Rp10 juta dalam jangka waktu satu tahun. Jika Pak D telah membayar semua kewajibannya (sebesar utang pokok Rp.10 juta plus bunga) sesuai perjanjian, maka perjanjian tersebut dengan sendirinya berakhir. Berakhirnya perjanjian karena pembayaran diatur dalam Pasal 1382-1403 KUHPerdata. Pelunasan utang oleh Debitur dapat berbentuk uang tunai, barang, atau jasa. ${ }^{16)}$

2. Batal atau Pembatalan Perjanjian : Berakhirnya suatu kontrak/perjanjian juga dapat terjadi karena faktor pembatalan kontrak sebagaimana diatur dalam Pasal 1446-1456 KUH Perdata. Pembatalan kontrak dapat disebabkan karena:

a. adanya perjanjian yang dibuat oleh orang-orang yang belum dewasa dan atau di bawah pengampuan;

b. Tidak mengindahkan bentuk perjanjian yang dipersyaratkan dalam Undang-Undang;

c. Adanya cacat kehendak seperti kekhilafan, paksaan, dan penipuan. ${ }^{17)}$

Perjanjian Investor yang telah dibatalkan tersebut apabila merujuk pada 2 hal yakni yang pertama asas Lex Posterior Derogat Legi Priori yang merupakan asas dimana ketentuan-ketentuan yang sekarang mengenyampingkan ketentuan-ketentuan lebih dulu. ${ }^{18)}$, dan yang kedua yakni teori kepastian hukum, dimana teori kepastian hukum adalah terlaksananya undang-undang atau peraturan dalam praktiknya. ${ }^{19)}$ Maka, perjanjian investor yang telah dibatalkan tersebut sudah seharusnya tidak

16) Iswi Hariyani dan Cita Yustisia, Merger, Konsolidasi, Akuisisi dan Pemisahan Perusahaan. (Jakarta : Visimedia, 2011), hal. 50.

17) Ibid, hal. 52

18) Nommy Horas Thombang Siahaan, Hukum lingkungan dan ekologi pembangunan. (Jakarta: Erlangga, 2004), hal. 373.

${ }^{19)}$ E.Fernando M.Manullang, Legisme, Legalitas dan Kepastian Hukum, Cetakan ke1. (Jakarta: Kencana, 2016), hal.158. 
dapat hidup kembali dan diperkuat dengan statement dari bapak Ariawan Gunadi bahwa Perjanjian Investor yang telah dibatalkan dalam kasus ini hanya dapat dijadikan sebagai bukti di pengadilan tetapi tidak dapat dijadikan sebagai salah satu pertimbangan Hakim untuk dapat memutus Akta Hibah batal demi hukum. ${ }^{20}$ Mengapa demikian? Karena Perjanjian Investor tersebut yang bersifat Posterior telah digantikan dengan perjanjian pengakhiran dan pelepasan yang bersifat Priori yang kemudian membuat Perjanjian Investor yang telah dibatalkan tersebut menjadi tidak berlaku lagi, dan apabila putusan yang diangkat kemudian dikaitkan dengan teori kepastian hukum, maka jelas antara putusan dengan teori tersebut telah bertentangan satu sama lain. Berdasarkan pada teori kepastian hukum, seharusnya putusan yang diputus oleh Hakim tidak menimbulkan keragu-raguan atau multi-tafsir dan logis sehingga tidak bertentangan atau bahkan menimbulkan konflik norma. Tetapi pada kenyataannya, keputusan Hakim dalam memutus akta hibah batal demi hukum dengan mempertimbangkan pada perjanjian investor yang telah dibatalkan sebelum Penggugat membawa kasus ini ke Pengadilan membuat adanya suatu keragu-raguan pada keputusan Hakim tersebut. Jadi seharusnya Hakim tidak memutus Akta Hibah tersebut batal demi hukum dengan salah satunya mempertimbangkan pada perjanjian investor yang telah dibatalkan tersebut.

\section{B. Kedudukan Perjanjian Investor terhadap Akta Hibah berdasarkan}

\section{Putusan Mahkamah Agung Nomor 2820 K/Pdt/2014}

Kedudukan Perjanjian Investor terhadap Akta Hibah dalam kasus ini adalah dengan melihat terlebih dahulu mana yang lahir duluan diantara dua perjanjian ini. Pada kasus ini, perjanjian yang lahir duluan adalah Akta Hibah yang lahir pada tanggal 12 dan 13 Nopember 2007. Akta Hibah ini dibuat oleh pejabat yang berwenang yakni Notaris Karin

20) Peneliti, Wawancara, dengan Ariawan Gunadi (Jakarta: Universitas 
Christiana Basoeki, S.H. Sedangkan Perjanjian Investor lahir pada tanggal 27 Nopember 2007 dan dibuat dengan kesepakatan bersama. Dari hasil wawancara dengan bapak Ariawan Gunadi, kemudian dapat menyimpulkan bahwa antara Akta Hibah dan Perjanjian Investor pada kasus ini memiliki kedudukan yang berbeda. Mengapa antara kedudukan Akta Hibah dengan Perjanjian Investor dalam kasus ini berbeda? Dikatakan berbeda adalah dengan melihat bahwa kedudukan kedua perjanjian ini tidak sejajar dan bukan merupakan 1 paket serta tidak saling terkait satu sama lain. Maksud dari kedudukannya tidak sejajar adalah bawa Akta Hibah yang merupakan Akta Notariil sudah jelas berbeda dan tidak sejajar dengan Perjanjian Investor yang merupakan Akta Bawah Tangan. Akta Hibah dalam kasus ini adalah sebuah Akta Notariil yang telah disepakati oleh antar pihak yang hendak melakukan sebuah penghibahan atas saham hak milik dalam suatu perusahaan. Akta Hibah sebagai Akta Notariil diklasifikasikan sebagai Akta Otentik dan bukan Akta Bawah Tangan. Sedangkan Perjanjian Investor dalam kasus ini digolongkan sebagai Akta Bawah Tangan. Perbedaan antara Akta Otentik dengan Akta Bawah Tangan terletak pada :

a. Akta Otentik : Akta Otentik merupakan akta yang dibuat dalam bentuk yang ditentukan oleh undang-undang, dibuat oleh atau di hadapan pejabat umum yang berwenang untuk itu di tempat akta itu dibuat dan memiliki nilai pembuktian yang sempurna. Dalam ruang sidang pengadilan, akta otentik merupakan alat bukti yang tidak dapat disangkal, kecuali pihak lawan dapat menyangkal kebenarannya dan penyangkalan itu harus dibuktikan. ${ }^{21)}$

b. Akta di bawah tangan : Akta di bawah tangan dapat dibuat secara bebas oleh para pihak dan undang-undang tidak menentukan format khususnya. Pasal 1874 KUHPerdata menentukan bahwa tulisan di bawah tangan adalah akta yang ditandatangani di bawah tangan tanpa

21) Dadang Sukandar, Panduan Membuat Kontrak Bisnis, (Jakarta : Visimedia, 2017), hal. $44-45$. 
perantaraan seorang pejabat umum. Akta di bawah tangan dapat dibuat secara bebas oleh para pihak yang berkepentingan tanpa melibatkan pejabat umum. Berbeda dengan akta otentik, akta di bawah tangan tidak memiliki kekuatan bukti yang sempurna. Hal ini berarti pihakpihak yang membuat akta di bawah tangan harus membuktikan bahwa isi akta tersebut adalah benar. ${ }^{22)}$

Kemudian dikatakan tidak 1 paket adalah dikarenakan Akta Hibah tersebut bukanlah perjanjian induk dari Perjanjian Investor, demikian pula Perjanjian Investor yang tidak dapat dikatakan sebagai perjanjian rujukan dari Akta Hibah. Mengapa demikian? Karena walaupun Akta Hibah tersebut lahir sebelum Perjanjian Investor, keduanya tidak terkait dengan melihat pada fakta yang ada, baik dalam Akta Hibah maupun Perjanjian Investor tidak terdapat kata-kata yang menjadikan mereka saling terkait. Sehingga, antara Akta Hibah dan Perjanjian Investor merupakan perjanjian yang masing-masing berdiri sendiri. Jadi dengan telah dibatalkannya Perjanjian Investor dengan Akta Pengakhiran dan Pelepasan, maka Hakim seharusnya tidak bisa memutus bahwa Akta Hibah tersebut batal demi hukum apabila salah satu pertimbangannya melihat pada Perjanjian Investor tersebut. Mengapa? Karena kedua perjanjian ini merupakan 2 entitas yang berbeda. Perjanjian Investor yang telah dibatalkan yang kemudian diajukan sebagai bukti ke pengadilah adalah hal yang diperbolehkan atau sah-sah saja. Tetapi apabila kemudian dijadikan sebagai salah satu pertimbangan Hakim untuk membatalkan Akta Hibah, bukanlah hal yang benar dan seharusnya hakim tidak bisa memutus hal tersebut melihat bahwa kedua perjanjian tersebut merupakan hal yang berbeda yakni masing-masing perjanjian berdiri sendiri dan saling tidak terkait, serta kedudukannya saling tidak sejajar.

22) Ibid, hal. 45. 


\section{Penutup}

\section{A. Kesimpulan}

Berdasarkan pada pokok permasalahan yang telah dibahas dan dianalisis, maka kesimpulan dan saran sebagai berikut:

1. Perjanjian Investor yang dilakukan antar pihak pada kasus ini dibuat secara sah karena telah memenuhi syarat sahnya suatu perjanjian seperti yang tercantum dalam Pasal 1320 KUHPerdata. Perjanjian tersebut tidak lahir dengan dilatarbelakangi oleh akta hibah karena tidak adanya keterkaitan antara kedua perjanjian, dan bahwa perjanjian investor tersebut berdasarkan pada Pasal 1338 KUHPerdata sehingga berlaku seperti Undang-Undang yang mengikat para pihak.

2. Merujuk pada teori argumentasi hakim, dan melihat bahwa salah satu pertimbangan Hakim menyatakan bahwa adanya syarat pembayaran dalam terjemahan ketentuan Perjanjian Investor Pasal 3.1 yang tercantum didalam putusan pada faktanya tidak sesuai dengan terjemahan Perjanjian Investor yang telah diserahkan oleh pihak Kuasa Hukum Tergugat ke Pengadilan, maka kesalahan terjemahan tersebut mengakibatkan makna atau dampak hukum yang berbeda. Makna terjemahan yang berbeda yang tercantum dalam suatu putusan memungkinkan suatu kondisi yang menyebabkan Hakim menjadi salah menafsirkan dan berdampak pada putusan yang diberikan. Suatu penerjemahan bahasa merupakan salah satu hal penting bagi Hakim untuk memutus suatu perkara yang apabila terjadi kesalahan penerjemahan bahasa baik disengaja maupun tidak disengaja akan mempengaruhi putusan Hakim tersebut.

3. Perjanjian Investor yang telah dibatalkan tersebut merujuk pada asas Lex Posterior Derogat Legi Priori dan teori kepastian hukum sudah seharusnya tidak dapat hidup kembali. Perjanjian Investor yang telah dibatalkan dalam kasus ini hanya dapat dijadikan sebagai 
bukti di pengadilan tetapi tidak dapat dijadikan sebagai salah satu pertimbangan Hakim untuk dapat memutus Akta Hibah batal demi hukum, karena perjanjian Investor tersebut yang bersifat Posterior telah digantikan dengan perjanjian pengakhiran dan pelepasan yang bersifat Priori yang kemudian membuat Perjanjian Investor yang telah dibatalkan tersebut menjadi tidak berlaku lagi, dan dengan teori kepastian hukum, maka jelas antara putusan dengan teori tersebut telah bertentangan satu sama lain. Berdasarkan pada teori kepastian hukum, seharusnya putusan yang diputus oleh Hakim tidak menimbulkan keragu-raguan atau multi-tafsir dan logis sehingga tidak bertentangan atau bahkan menimbulkan konflik norma. Tetapi pada kenyataannya, keputusan Hakim dalam memutus akta hibah batal demi hukum dengan mempertimbangkan pada perjanjian investor yang telah dibatalkan sebelum Penggugat membawa kasus ini ke Pengadilan membuat adanya suatu keraguraguan pada keputusan Hakim tersebut. Jadi seharusnya Hakim tidak memutus Akta Hibah tersebut batal demi hukum dengan salah satunya mempertimbangkan pada perjanjian investor yang telah dibatalkan tersebut.

4. Mengenai kedudukan Perjanjian Investor terhadap Akta Hibah dalam kasus ini memiliki kedudukan yang berbeda. Dikatakan berbeda adalah dengan melihat bahwa kedudukan kedua perjanjian ini tidak sejajar dan bukan merupakan 1 paket serta tidak saling terkait satu sama lain. Maksud dari kedudukannya tidak sejajar adalah bawa Akta Hibah yang merupakan Akta Notariil sudah jelas berbeda dan tidak sejajar dengan Perjanjian Investor yang merupakan Akta Bawah Tangan. Akta Hibah dalam kasus ini adalah sebuah Akta Notariil yang telah disepakati oleh antar pihak yang hendak melakukan sebuah penghibahan atas saham hak milik dalam suatu perusahaan. Akta Hibah sebagai Akta Notariil diklasifikasikan sebagai Akta Otentik dan bukan Akta Bawah Tangan. Sedangkan 
Perjanjian Investor dalam kasus ini digolongkan sebagai Akta Bawah Tangan. Perbedaan antara Akta Otentik dengan Akta Bawah Tangan terletak pada :

a. Akta Otentik : Akta otentik dibuat berdasarkan peraturan perundang-undangan dan dibuat oleh pejabat umum yang berwenang. Dalam hal pembuktian, Akta Otentik mempunyai kekuatan pembuktian yang sempurna. Kekuatan pembuktian yang sempurna adalah bahwa Akta Otentik adalah benar, kecuali pihak lain dapat menyangkal kebenarannya.

b. Akta Bawah Tangan : Akta Bawah Tangan dapat berupa surat atau tulisan yang dibuat oleh para pihak, dan tidak dibuat oleh pejabat umum yang berwenang. Berbeda dengan Akta Otentik, kekuatan pembuktian Akta Bawah tangan tidak sesempurna Akta Otentik.

Kemudian dikatakan tidak 1 paket adalah dikarenakan Akta Hibah tersebut bukanlah perjanjian induk dari Perjanjian Investor, demikian pula Perjanjian Investor yang tidak dapat dikatakan sebagai perjanjian rujukan dari Akta Hibah. Karena walaupun Akta Hibah tersebut lahir sebelum Perjanjian Investor, keduanya tidak terkait dengan melihat pada fakta yang ada, baik dalam Akta Hibah maupun Perjanjian Investor tidak terdapat kata-kata yang menjadikan mereka saling terkait. Sehingga, antara Akta Hibah dan Perjanjian Investor merupakan perjanjian yang masing-masing berdiri sendiri. Kedua perjanjian ini merupakan 2 entitas yang berbeda. Perjanjian Investor yang telah dibatalkan yang kemudian diajukan sebagai bukti ke pengadilan adalah hal yang diperbolehkan atau sah-sah saja. Tetapi apabila kemudian dijadikan sebagai salah satu pertimbangan Hakim untuk membatalkan Akta Hibah, bukanlah hal yang benar dan seharusnya hakim tidak bisa memutus hal tersebut melihat bahwa kedua perjanjian tersebut merupakan hal 
yang berbeda yakni masing-masing perjanjian berdiri sendiri dan saling tidak terkait, serta kedudukannya saling tidak sejajar.

\section{B. Saran}

1. Saran Bagi Hakim

Saran yang dapat diberikan bagi Hakim adalah sebaiknya Hakim lebih bijaksana dan sesuai pada hukum yang berlaku dalam memberikan suatu putusan agar putusan yang diberikan menjadi pasti dan tidak menimbulkan suatu keragu-raguan.

2. Saran Bagi Pemberi Hibah

Saran yang dapat diberikan bagi pemberi hibah yang dalam hal ini yaitu orang yang memberikan hibah kepada orang lain untuk lebih berhati-hati dalam memberikan hibah agar terhindar dari kerugian-kerugian baik materiil maupun imateriil.

3. Saran Bagi Penerima Hibah

Saran yang dapat diberikan bagi penerima hibah yang dalam hal ini yaitu orang yang menerima hibah dari pemberi hibah untuk lebih berhati-hati dalam menerima hibah dan haruslah memiliki itikad yang baik dalam menerima hibah itu sendiri.

4. Saran bagi Masyarakat

Saran yang dapat diberikan bagi Masyarakat adalah sebaiknya masyarakat lebih berhati-hati dalam melakukan suatu perbuatan hukum, karena perbuatan hukum menyebabkan timbulnya suatu hak dan kewajiban yang harus dilakukan. Masyarakat harus selalu waspada akan hal-hal yang dapat merugikan dan selalu waspada dalam melakukan sebuah perjanjian atau perikatan dengan pihak lain, agar perjanjian yang terlaksana dapat berjalan sesuai dengan hukum yang berlaku dan tidak merugikan satu sama lain.

\section{Daftar Pustaka}




\section{A. Buku}

Hariyani, Iswi dan Cita Yustisia. Merger, Konsolidasi, Akuisisi dan Pemisahan Perusahaan. Jakarta : Visimedia, 2011.

Manullang, E.Fernando M. Legisme Legalitas dan Kepastian Hukum. Jakarta: Kencana, 2016.

Mertokusumo, Sudikno. Mengenal Hukum Suatu Pengantar. Yogyakarta: Liberty,1986.

Rapar, Philipus Hendrik. Argumentasi Hukum, Yogyakarta : Penerbit Gajah Mada University Press, 2009.

Sembiring, Sentosa. Hukum Perusahaan Tentang Perseroan Terbatas, Nuansa, Bandung : Nuansa Aulia, 2006.

Siahaan, Nommy Horas Thombang. Hukum lingkungan dan ekologi pembangunan. Jakarta: Erlangga, 2004.

Sidharta, Arif . Karakteristik Penalaran Hukum dalam Konteks Keindonesiaan, Bandung : CV. Utomo,2006.

Subekti. Aneka Perjanjian. Bandung : Citra Aditya Bakti,1995. . Hukum Perjanjian. Jakarta : Intermasa, 1979. Hukum Perjanjian, Cetakan ke-18. Jakarta: Intermasa, 2001. Pokok-Pokok Hukum Perdata. Jakarta: intermasa, 2010.

Sukandar, Dadang. Panduan Membuat Kontrak Bisnis, Jakarta : Visimedia, 2017.

\section{B. Peraturan Perundang-Undangan}

Indonesia. Kitab Undang-Undang Hukum Perdata

Perusahaan

$$
\text { Undang-Undang Nomor } 8 \text { tahun } 1997 \text { tentang Dokumen }
$$

. Undang-Undang Nomor 40 tahun 2007 tentang Perseroan

Terbatas

Terbatas

Undang-Undang Nomor 40 tahun 2007 tentang Perseroan 


\section{Putusan Pengadilan}

Indonesia. Putusan Pengadilan Negri Jakarta Selatan Nomor 605/Pdt/G/2011/Pn Jkt. Sel.

Putusan Mahkamah Agung Republik Indonesia Nomor 2820

$\mathrm{K} / \mathrm{Pdt} / 2014$

\section{Artikel Internet}

Tunardy, Wibowo. http://www.jurnalhukum.com/jenis-jenis-perjanjian/ (10 Mei 2018)

\section{E. Wawancara}

Peneliti, Wawancara, dengan Ning Adiasih, (Jakarta: Universitas

Tarumanagara Jakarta Barat, 25 April 2018).

Peneliti, Wawancara, dengan Ariawan Gunadi (Jakarta: Universitas

Tarumanagara Jakarta Barat, 30 Mei 2018). 